\title{
A plea for transparency in Canada's "new government"
}

Published at www.cmaj.ca on Feb. 7, 2007.

$\mathrm{O}$ n Dec. 2I, 2006, Health Minister Tony Clement announced the appointments of a chair, a president and 8 board members for Assisted Human Reproduction Canada. ${ }^{1}$ This new federal agency is charged with regulating fertility clinics, making decisions about research that uses human embryonic stem cells and advising Mr. Clement about assisted human reproduction. ${ }^{2}$ But for an agency entrusted with Canadians' reproductive well-being, it has had a protracted and problematic birth. The end result is that only 2 of that total of ro board members were among the 25 people recommended by an expert selection committee, one convened by Health Canada under the previous Liberal government. A spokesperson for Mr. Clement told CMAJ that the "new government" wasn't satisfied with the original short list, and sought broader representation. The opposite appears to have happened. At least 4 of the board's 8 (nonexecutive) members have publicly declared a socially conservative perspective on issues directly related to the board's mandate, and the chair has political ties to the Conservative Party. Moreover, there is a notable absence of experts in fertility treatment and stem cell research. Worse still, the board has no patient representatives whatsoever.

Why should Canadians care? Because human embryonic stem-cell research, fertility services and issues related to reproductive technologies have proven time and again to resonate with ethical and moral choices that reverberate well outside the medical and scientific domains. A sensitive, broadly representative and, above all, transparent approach to selecting the members of this board would give the new agency legitimacy before it faces its difficult choices. It is alarming that Prime Minister Stephen Harper's "new government," the same one that passed the Accountability Act ${ }^{3}$ and campaigned on transparency in the 2006 election, appears to have interfered with a heavy hand in the selection of the leadership and board of Assisted Human Reproduction Canada.

Imagine the selection committee's surprise when the federal government all but ignored its carefully considered choices. This decision not only wasted the committee members' time and taxpayers' money (the selection committee met for 2 days, which cannot have been cheap), it also set a precedent for how the government treats academics whom it solicits for expert advice. The current government appears to have made a mockery of the original process, in which all qualified Canadians were invited to submit their names as potential board members.

The unmistakable signal sent is that the current government values control more than transparency in decision-making; favours ideology over scientific and clinical expertise; and believes that patient representation is altogether dispensable. We fear that even if the board allows expert and public input into all issues, and publishes its deliberations, the controversy surrounding its creation, the lack of patient representatives and the apparent socially conservative biases of some members will mar the institution and will haunt the agency's future work. The United States has been ill-served when successive Administrations, both Democrat and Republican, turned reproductive health into a political football. Without consistency, US reproductive health policies have become socially divisive and are affecting access to care.

Is this what we want in Canada?

Mr. Clement does have some options. He could dismiss the agency's board and return to the original short list, or he could expand the current board of ro members to $\mathrm{I}_{3}$, the maximum allowed by law. His new members could be drawn from the short list and include fertility experts, stem cell researchers and, most importantly, patient representatives.

However, even if Mr. Clement chooses one of these courses of action, the government's reputation has still been damaged. Its decision to ignore its own expert selection committee raises a larger question of transparency. This government should carefully reconsider its position on this issue, and the opposition parties should ensure that this government respects its self-imposed accountability agenda. Until then, if you are called upon to serve upon an expert advisory panel, you might want to think twice; your time could perhaps be spent to greater effect, elsewhere.

\section{Paul C. Hébert}

Editor-in-Chief, CMAJ

\section{Amir Attaran}

Canada Research Chair in Law, Population Health and

Global Development Policy

University of Ottawa

for the CMAJ Editorial-Writing Team (Paul C. Hébert, Amir Attaran, Noni MacDonald and Ken Flegel)

Ottawa, Ont.

\section{REFERENCES}

I. Assisted Human Reproduction Act. SC 2004, c. 2. Available: http://laws.justice.gc .ca/en/ShowFullDoc/cs/a-13.4///en (accessed 2007 Feb I).

2. Eggertson L. New reproductive technology board belies expert selection process. CMAJ 2007;I76 (5):6II-2.

3. The Federal Accountability Act. SC 2006, c. 2. Available: www.parl.gc.ca/common /bills_ls.asp?lang=E\&ls=c2\&source=library_prb\&Parl=39\&Ses=1 (accessed 2007 Feb I). 